\title{
ORGANISATIONAL AND ECONOMIC ACTIVITIES FOR PROVISION OF MEDICAL REHABILITATION SERVICES ON AN OUTPATIENT BASIS TO PATIENTS THAT HAVE SUFFERED AN ACUTE CEREBROVASCULAR ACCIDENT
}

\author{
Lilia Badrutdinova ${ }^{1}$ and Olga Manerova
}

${ }^{I}$ N.A.Semashko, Department of Public Health and Healthcare,

I.M. Sechenov First Moscow State Medical University, Moscow, Russian Federation

\section{ORGANIZACIONE I EKONOMSKE AKTIVNOSTI ZA SPROVO円ENJE MEDICINSKE REHABILITACIJE U AMBULATNIM USLOVIMA BOLESNIKA KOJI SU DOŽIVELI AKUTNI CEREBROVASIKULARNI DOGADAJ}

\author{
Lilia Badrutdinova ${ }^{1}$ i Olga A. Manerova \\ ${ }^{I}$ N.A.Semasko, Katedra za javno zdravlje i zdravstvenu zaštitu, \\ I.M. Sečenov prvi moskovski državni medicinski univerzitet, Moskva, Ruska Federacija
}

\begin{abstract}
The aim of this study was to develop legal, organizational and economic activities for providing medical rehabilitation on an outpatient basis to patients that have suffered an acute cerebrovascular accident (CVA). The study included patients who had suffered a CVA and were undergoing medical rehabilitation on an outpatient basis (400 individuals participated in a retrospective study and 400 individuals took part in a sociological survey) and medical rehabilitation specialists providing care on an outpatient basis to patients who had suffered a CVA $(n=50)$. All included patients received medical rehabilitation in accordance with the Guidelines of the Ministry of Health of the Russian Federation (No: 70). It should be noted that patients who suffered a CVA occupy a central place in the system of medical rehabilitation performed on an outpatient basis. Medical rehabilitation is important for their medical and social characteristics, motivation, environment, adherence to treatment and a healthy lifestyle. In accordance with the above mentioned, the following activities should be planned and implemented: a) work with doctors, b) work with patients; c) work with patients' relatives; d) organizational aspects, and e) economic aspects. When organizing medical rehabilitation on an outpatient basis, it should be considered as a system of interaction between all participants in the rehabilitation process, in the center of which the patient is located. The main organizational activity for conducting medical rehabilitation in an outpatient setting is the implementation of a comprehensive interaction of all participants in the rehabilitation process.
\end{abstract}

Keywords: stroke, medical rehabilitation, organization of health care system.

\section{SAŽETAK}

Cilj ove studije je bio razvijanje pravnih, organizacionih i ekonomskih aktivnosti za sprovođenje medicinske rehabilitacije u ambulantnim uslovima pacijenata koji su doživeli akutni cerebrovaskularni događaj (CVI). Studija je obuhvatala pacijente koji su u istoriji bolesti imali CVI i bili su medicinski rehabilitovani u ambulantnim uslovima (400 ljudi je učestvovalo u retrospektivnoj studiji, 400 ljudi u sociološkom istraživanju) i specijaliste koji su obavljali medicinsku rehabilitaciju za pacijente sa CVI $(n=50)$. Svi pacijenti koji su bili uključeni dobili su medicinsku rehabilitaciju u skladu sa članom 70 Ministarstva zdravlja Ruske Federacije. Treba napomenuti da pacijent koji je imao CVI ima visok značaj $i$ zaokuplja pažnju u sistemu medicinske rehabilitacije. Medicinska rehabilitacija u ambulatnim uslovima je veoma važna u pogledu njegovih medicinskih $i$ socijalnih karakteristika, motivacije, njegovog okruženja, pridržavanja tretmana $i$ zdravog načina života. U skladu sa tim, plan je sprovesti sledece aktivnosti: a) rad sa doktorima; b) rad sa pacijentima; c) rad sa okruženjem; d) organizacioni aspekti i e) ekonomski aspekti. Prilikom organizovanja medicinske rehabilitacije $u$ ambulantnim uslovima, treba imati $u$ vidu sistem interakcija između učesnika u procesu rehabilitacije, u čijem centru se nalazi pacijent. Glavna organizaciona aktivnost za sprovođenje medicinske rehabilitacije u ambulantnim uslovima je sprovođenje sveobuhvatne interakcije svih učesnika u procesu rehabilitacije.

Ključne reči: moždani udar, medicinska rehabilitacija, organizacija sistema zdravstvene zaštite.
Corresponding author: Lilia Badrutdinova N.A. Semashko Department of Public Health and Healthcare I.M. Sechenov First Moscow State Medical University, Moscow, Russian Federation
E-mail: lili-019@mail.ru 


\section{INRODUCTION}

At the present stage of development of health care systems in the economically developed countries of the world, one of the priority problems of strengthening and preserving health of the population is reducing the mortality rate due to the circulatory system diseases. In the structure of the causes of mortality in Russia, these diseases have occupied the first place, from the middle of the twentieth century to the present days. In 2016 and 2017, they accounted for more than $50 \%$ of deaths among the country's population $(1,2)$.

A special role in resolving this problem should be given to activities aiming to improve prevention and organization of medical care and rehabilitation for patients with acute cerebrovascular accident (CVA). Almost half of the patients who suffered a CVA die in the first year after their stroke, and only about $20 \%$ of the sick return to work $(2,3)$.

There are different options for managing patients who have had a CVA, after completing their treatment in an intensive care unit. One of the options is the recommendation that most patients after discharge from an intensive care unit should be in a rehabilitation hospital. Other options are that some patients should undergo treatment in a hospital, and others who have a mild neurological deficit should receive rehabilitative treatment on an outpatient basis. The organization of targeted quality rehabilitation care at the outpatient stage is one of the directions in the reform of medical care $(3,4)$.

Monitoring of the treatment and observation of long-term treatment outcomes are some of the main duties of doctors (neurologists, surgeons, orthopedists, physiotherapists, and rehabilitation specialists), and this group of specialists has a responsibility to follow up with their patients for a long time $(4,5)$.

Medical rehabilitation of patients with CVA is a task of supreme importance, as the number of patients grows each year, and the number of severe forms of this pathology accompanied by profound neurological deficits simultaneously increases. This clinical picture leads to a permanent loss of ability to work, most often due to late treatment of patients in an outpatient care unit. The timing of admission to the outpatient unit of the health system is often missed, often due to the lack of recommendations on the timing of admission of patients that have had a CVA on an outpatient basis (5-7).

In modern conditions of healthcare development, it is necessary to improve the continuity of therapeutic, diagnostic, rehabilitation and health-improving activity at all levels of care. First of all, it concerns the activities that are carried out at the stage of outpatient rehabilitation (8). A timely rehabilitation will prevent disability of patients and facilitate a return of the able-bodied population to work, thereby reducing the economic burden on the society and the state (9).

This applies not only to the choice of medical support to patients, but also to the organization of the third stage of reha- bilitation as a system where the patient reaches the maximum possible effect for the degree of his or her neurological deficit and one of the main criteria for successful rehabilitation is a return to work. According to that, the aim of the study was to develop legal, organizational and economic activities for provision of medical rehabilitation services on an outpatient basis to patients who have suffered an acute cerebrovascular accident.

\section{MATERIALS AND METHODS}

\section{Study protocol}

The study was conducted at the Polyclinic centers of the Moscow City Health Department, Moscow, Russia, on the patients with diseases of the central and peripheral nervous system and who used medical rehabilitation on an outpatient basis. Patients are sent to the polyclinic from hospitals, outpatient centers, city polyclinics and outpatient clinics of Moscow and the Moscow region. In the period from 2011 to 2015, patients were admitted to treatment from the city polyclinics, hospitals, and their request. The study was implemented in the period from 2015 to 2018 (the analysis of data from the primary medical documentation for the period from 2011 to 2015 was carried out retrospectively).

\section{Study population}

The subjects of the study were patients who had suffered a CVA and were undergoing medical rehabilitation on an outpatient basis (400 individuals participated in a retrospective study and 400 individuals took part in a sociological survey) and specialists providing medical rehabilitation on an outpatient basis for patients who had suffered a CVA $(n=50)$. All included patients received medical rehabilitation in accordance with Article 70 of the Decree of Ministry of Health of the Russian Federation dated 29 December, 2012 No. 1705n "On the order of organization of medical rehabilitation". Randomization was carried out by mechanical selection.

The main inclusion criteria were: written informed consent of a patient to participate in the research; age above 18 years; diagnosis of "cerebral infarction" (code I 63 according to ICD10) or "transient ischemic attack" (code G 45 according to ICD-10); conducting rehabilitation activities in an outpatientpolyclinic medical organization.

The main exclusion criteria were: age less than 18 years; patient's refusal to further participate in the research; focal lesions of the brain, which developed as a result of other causes not related to CVA; lack of data about the implementation of rehabilitation activity at the third stage; patient's failure to further participate in the research. 


\section{Data collection}

During the study, the primary medical documentation was selected, the volume of the sample was calculated, the data was copied from the primary medical documentation (form 025/y "Medical card of the outpatient"), and the received information was entered in the appropriate database. The data mining map included the following sections:

I Passport part (socio-demographic characteristics of the patient);

II Information about the CVA;

III Information about the medical therapy and use of nondrug rehabilitation methods;

IV Information about the consultations provided by specialists of different profiles;

V Conducted sanatorium-and-spa treatment.

The sociological research of patients and specialists was carried out on the basis of analysis of questionnaires that were specially developed for the corresponding group of respondents. The complex methodology of scientific research included the following methods: analytical, organizational, sociological, economic analysis, economic modeling, comparative and statistical analysis, content analysis, and intellectual analysis of data.

\section{RESULTS AND DISCUSSION}

\section{Basic socio-demographic characteristics of the study population}

The average age of a patient undergoing medical rehabilitation on an outpatient basis was 54.07 years, and $50.2 \%$ of the able-bodied age group. The structure of patients was dominated by individuals whose occupation was associated primarily with intellectual work $(71.1 \%)$ in the area of higher education $(64.25 \%)$. The relationship between the level of education and a good prognosis of medical rehabilitation, in persons with higher education, was the following among women $(\mathrm{r}=0.83, \mathrm{p}<0.001)$ and among men $(\mathrm{r}=0.93$, $\mathrm{p}<0.001)$.

\section{Clinical characteristics of the study population}

The overwhelming majority of patients had no disability $(80.6 \pm 1.9 \%)$. More than half $(68.7 \pm 2.5 \%)$ of the patients had suffered a CVA for the first time. The clinical picture was characterized mainly by vestibule-cerebellar disorders $(65.9 \pm$ $1.1 \%)$, motor reflex $(14.8 \pm 2.2 \%)$, and disorders of cranial nerves $(11.8 \pm 2.2 \% \%)$.
The average duration of rehabilitation activity performed on an outpatient basis was 28.3 days. Patients who had suffered a CVA and were undergoing rehabilitation were consulted by doctors - neurologists, physicians, physiotherapists, ophthalmologists, and cardiologists.

An important characteristic of a stroke patient is a restriction of his or her vital activity. Restriction in labor activity was experienced by $77.8 \% \pm 3.2 \%$ of the patients and restriction in self-service was experienced by $55.3 \% \pm 3.5 \%$ of the patients. There was also a violation of orientation in space $(81.2 \% \pm 2.8 \%)$, a restriction in movement $(11.5 \% \pm 3.8 \%)$ training $(5.7 \pm 1.5 \%)$, and communication $(4.1 \pm 1.3 \%)$. Moreover, $47.8 \pm 2.4 \%$ of the respondents showed a significant degree of dependence in the household activity and the evaluation was carried out using the Barthel-index.

\section{Satisfaction of patients with the health care system}

Satisfaction with the services of medical rehabilitation in outpatient conditions on a 5-point scale was $3.46 \pm 0.9$ points, depending on a number of factors. High evaluation of the provided services was given by individuals aged 61 to 70 years, and taking into account a work history, those were working patients with higher education. Patient's satisfactio $n$ is also determined by the state of their health. It was revealed that the lower the patient's subjective assessment of his or her health, the lower the satisfaction rating $(r=+0.86, p=0.010)$. At the same time, low satisfaction ratings were noted among those who did not consider it necessary to monitor their lifestyle and adjust it. Low ratings of satisfaction with medical rehabilitation on an outpatient basis were associated with a shortage of staff and diagnostic equipment in the polyclinic, and an inadequate set of diagnostic and therapeutic activities.

\section{Activity implementation plan}

It should be noted that patients who have suffered a CVA occupy a central place in the system of medical rehabilitation performed on an outpatient basis. It is important for their medical and social characteristics, motivation, environment, adherence to treatment and a healthy lifestyle. In accordance with this, the following activities should be planned and implemented (Figure 1): a) Work with doctors; b) Work with patients; c) Work with relatives; d) Organizational aspects, and e) Economic aspects. Therefore, medical rehabilitation on an outpatient basis should be organized as a system of interaction between participants in the rehabilitation process, in the center of which the patient is located.

\section{Work with doctors}

Doctors, being the main sources of information about a patient's condition, should be fully involved in the rehabilitation of patients on an outpatient basis. As the results of the study showed, the best prognosis (according to the subjective estimates of the patient) is observed when the medical assistance was provided by an experienced specialist trained in medical rehabilitation. It is extremely important to maintain continuity and interdisciplinarity, which implies the involve- 
ment of subspecialists in preparation of an individual program for the rehabilitation of patients; however, $12.0 \pm 4.5 \%$ of the respondents did not take part in this. The implementation of this approach when working with doctors provides a basic principle for realization of medical rehabilitation for patients who suffered an acute cerebrovascular accident - complexity. At the same time, the basic factors influencing the positive outcome of medical rehabilitation are not only the complex work of all specialists (as $64.0 \pm 3.3 \%$ of specialists believe), but also the right therapy, and a strong-willed patient. This indicates the need for continuous, dynamic and comprehensive support for patients throughout the course of medical rehabilitation with the involvement of specialists such as a psychologist and psychotherapist.
The use of information materials and monitoring of the results should also be considered as some of the main organizational activities necessary to be implemented in everyday practice. At the same time, the obtained results of the study demonstrate a lack of understanding on the part of specialists what are the goals, objectives and mechanisms for monitoring rehabilitation process. More than half of the surveyed respondents do not monitor, since they believe that it is not their responsibility, and specialists do not know the goals, objectives and mechanisms for its implementation. Thus, it is necessary to upgrade the skills of specialists with a view to their preparation for the implementation of full-fledged and high-quality medical rehabilitation.

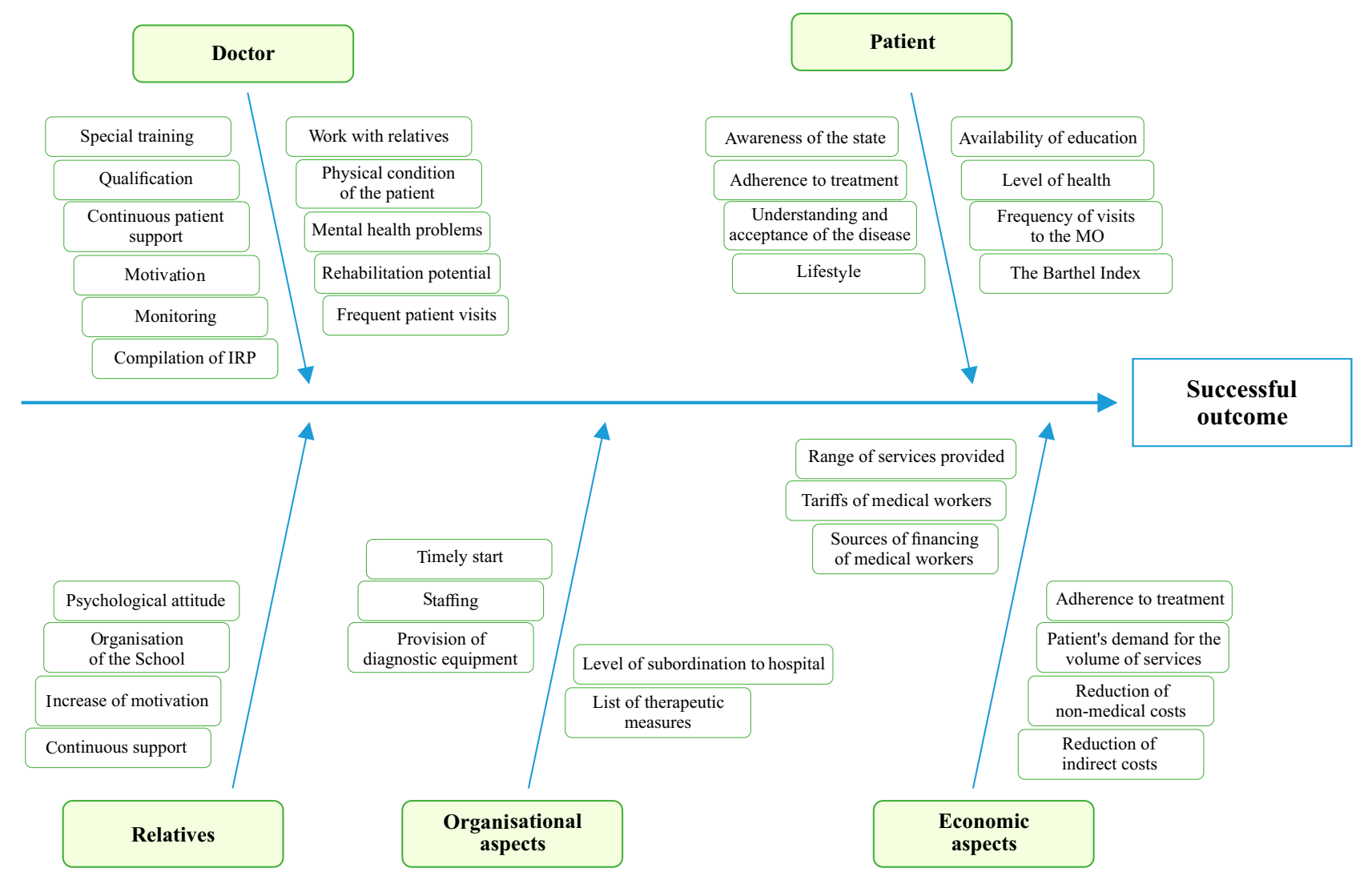

Figure 1. Organisational and management measures that promote successful outcome of medical rehabilitation on an outpatient basis 


\section{CONCLUSIONS}

The emotional-volitional factor of specialists performing medical rehabilitation has a special significance. Our study shows that $68 \%$ of the specialists, against a background of moderately high degree of maturity, lack motivation and, as a result, there is a decrease in their responsibility and awareness of their involvement in the task. The importance of this factor is determined by its direct influence on adherence to treatment of a particular patient and, as a consequence, on the outcome of the rehabilitation. When interacting with patients, it is important to take into account the frequency of their visits to the medical organization and the patient's rehabilitation potential. Specialists should pay attention to the patient's psychological state and physical condition. The results of the research show the need for specialists to interact with the patient's relatives for the purpose of their education and the correct approach to rehabilitation activity that can be carried out at home.

\section{Work with patients}

The next direction, which determines the success of rehabilitation, is working with patients. Namely, a positive outcome is influenced by the patient's satisfaction with the rehabilitation process. As a rule, highly educated individuals who also work at the time of the disease are more satisfied with rehabilitation activity.

An important aspect is the patient's state of health. The study demonstrated low interest of patients in maintaining a healthy life style; therefore, organizational activities should be aimed at establishing a "School of Health" and quality educational activities among patients. Patients, as immediate participants in the rehabilitation process, should be informed about their condition in order to understand and accept their illness. Clarification of these aspects is the task of medical staff. The success of rehabilitation directly depends on patient adherence to treatment, during which the patient needs a long and continuous support and, possibly, control during the patient's regular visits in the period of medical rehabilitation in a medical organization.

Of particular importance in forecasting a favorable outcome of medical rehabilitation is the magnitude of the Barthel-index. Obviously, the higher the index of daily activity, the better the rehabilitation forecast. However, patients with a low Barthel-index often enter rehabilitation on an outpatient basis. In this case, the goal of medical rehabilitation is to plan the maximum possible increase in the index of their daily activities.

\section{Work with relatives and friends}

Work with relatives and friends can qualitatively improve and accelerate the process of recovery. As the results of the study showed, both specialists and patients assigned an impor- tant place to this interaction in the medical organization where rehabilitation is carried out.

A significant number of patients with difficulties in daily self-care live with relatives and close people, thus being a burden on them. Virtually all patients with a Barthel index of less than 20 do not live alone, which means that a significant share of the costs falls not only in the form of direct costs for treatment, but also indirectly in the form of disability of the patients themselves and their relatives who are responsible to take care of them.

Relatives understanding of the goals and objectives of medical rehabilitation, as well as the availability of their capabilities and desire to provide all possible assistance in the implementation of an individual rehabilitation program are necessary for the full and correct implementation of the doctor's recommendations. In this regard, it would be convenient to organize special schools for relatives and friends of the patient in order to teach them how to take proper care of the patient and to explain the necessity of accompanying the patient throughout the course of medical rehabilitation.

\section{Organizational aspects}

Organizational aspects are essential for the success of medical rehabilitation. The favourable outcome of rehabilitation necessitates a resolution of a number of organizational problems, such as: lack of medical and nursing staff in a polyclinic at the place of residence and a shortage of diagnostic equipment.

A good prognosis is also influenced by appropriate medical activities. Some patients indicate a link between the prognosis and the level of medical organization, believing that federal medical organization provide better quality health care. With all the subjectivity of this opinion, as the research shows, it can affect the patient's psycho-emotional state and, as a result, the outcome of rehabilitation.

\section{Economic aspects}

Adherence to treatment by patients is significantly influenced by the source of funding for medical rehabilitation. The patient's demand for the volume of medical services depends on the source of funding. At the same time, the source of funding has an impact on the choice of specialists in the range of services assigned to patients for medical rehabilitation, which in turn also affects the outcome of treatment. Taking into account the incidence of CVA in Moscow, as well as the number of patients who can provide medical rehabilitation on an outpatient basis, the costs were very high, about 2 billion rubles. However, it should be noted that the state's payments in connection with indirect medical and indirect costs are made annually. Life expectancy in Russia in 2017 was 74 years; therefore, if we take into account that the average age of patients that have suffered a CVA is 54 years, the indirect medical expenses for this group of patients, taking also into account annual inflation, are 17,601,143,566 rubles. Thus, there is the possibility of preventing state expenses related to 
this category of patients, provided that patients are timely admitted to outpatient facilities. Based on the foregoing, it can be concluded that the costs of medical rehabilitation with a subsequent return to work are much lower than the costs borne by the state and society in case of failure of providing medical rehabilitation on an outpatient basis.

Thus, organizational, managerial, legal and economic activities for the implementation of medical rehabilitation on an outpatient basis should be aimed at the integrated interaction of all participants of the rehabilitation process. Specialists who provide medical rehabilitation should have the necessary qualifications and training and at the same time be in constant interaction with patients and their relatives for dynamic and continuous monitoring and monitoring of the results.

The patient, as the central link of the rehabilitation process, must have complete and reliable information about his state of health and understand the features of the current disease and its risks. At the same time, the patient is responsible for adjusting the lifestyle, with the aim of leveling the risk factors for the occurrence of repeated acute conditions.

Among legal tasks, an important aspect is the revision of territorial tariffs, and as a result, the expansion of the range of services provided to a patient served by the $\mathrm{CHI}$ tariff, and at the same time increasing the patient's demand for services and adherence to treatment. The sources of law regulating medical rehabilitation do not pay enough attention to the programs of medical rehabilitation and the continuous, long-term strategy for monitoring patients who have suffered a CVA, proceeding from individual characteristics of patients. As the economic analysis shows, non-medical and indirect costs faced by individuals in need of the third stage of rehabilitation can be reduced through their timely admission to this stage of rehabilitation.

\section{DISCUSSION}

Medical rehabilitation of patients who suffered a CVA is carried out in three stages. The first stage is carried out in the acute period of the course of the disease or trauma in intensive care units. The second stage should be carried out in the early recovery period of the disease or trauma, and the late rehabilitation period, as the period of residual phenomena of the course of the disease, should be the chronic course of the disease without exacerbation under hospital conditions of medical organizations (rehabilitation centers, rehabilitation departments). The third stage is carried out in the early and late rehabilitation periods by specialists who provide medical care on an outpatient basis, through doctors visiting patients at home and in the presence of the prospect of restoration of functions (rehabilitation potential) confirmed by the results of the survey.
The need to develop organizational and management activity for medical rehabilitation of patients who have suffered a CVA is caused by a significant increase in morbidity, mortality and a decrease of life quality among people of working age. Up to the third stage of medical rehabilitation, no more than $60 \%$ of patients survived after they had suffered a CVA. Despite the high importance of this problem, complex, continuous, and multidisciplinary medical rehabilitation with a return to work is foreseen only in a number of countries (9-11).

An analysis of regulatory documentation has shown that the Russian Federation does not have a legal basis needed for implementation of a medical rehabilitation program and there are no long-term strategies for continuous and integrated support for patients who have suffered a CVA. Professional communities are working on programming and organizing rehabilitation activities; however, the routing of such patients and their timely admission to the third stage of rehabilitation are not fully understood.

This situation requires international cooperation in the implementation of clinical guidelines, intersectional interaction of social and medical services, improving the understanding of financial departments of the need for investment in medical rehabilitation, as well as interdisciplinary cooperation to ensure better continuity of patients with CVA at different stages. It should be noted that the important organizational and managerial aspects are the complex interaction of the patient, the doctor, relatives, and also the satisfactory organizational and economic models for the organization of medical rehabilitation.

The following necessary activities should be organizational, legal and economic aspects of medical rehabilitation of CVA patients on an outpatient basis: participation of all specialists involved in patient rehabilitation programs in the preparation of individual rehabilitation programs before counseling or other medical assistance. Correctly chosen therapy and emotional-volitional state of mind of the patient should become another task for the doctor. Continuous, dynamic and comprehensive support of patients throughout the course of medical rehabilitation with the involvement of specialists such as a psychologist and psychotherapist can solve the task. In addition, increasing the number of patients who ongoing monitoring results by activity of specialists who provide care to patients (12).

There is an emotional-volitional factor of a specialist that influences adherence of patients to treatment and, as a result, a decrease in responsibility and awareness of their involvement in the task performed can result in an undesirable outcome of rehabilitation. One of the important organizational activities that can help to improve rehabilitation outcomes is patient satisfaction and interest in adherence to a recommendation and adherence to a healthy lifestyle. This task can be achieved through establishment of special "Schools of Health".

Patient's relatives and people close to the patient have a significant impact on the recovery process (13). It is necessary 
to conduct educational work among them for the rapid achievement of the goals and objectives of rehabilitation of the patient who has suffered a CVA. The lack of staff in a polyclinic at the place of residence and the shortage of diagnostic equipment are significant limitations in achieving a good outcome of rehabilitation $(7,13)$.

Patients who have suffered a CVA are a significant burden on society in cases of late or no admission to an outpatient facility, which proves the high economic efficiency of timely medical rehabilitation and continuous patient support.

Application of the obtained results in medical practice will allow improving the measures of the state policy, for people who have suffered a CVA, to predict long-term results of restoring damaged or compensated lost functions and determine the appropriateness of improving the legislative and materialtechnical base, forming the personnel potential of the industry, conducting activities in the direction of developing measures for disability prevention.

\section{CONCLUSION}

Specialists who carry out medical rehabilitation in outpatient settings note the need for a comprehensive individual rehabilitation plan and are engaged in drawing up an individual plan with other specialists or individually. When assessing organizational activities, specialists noted the need for continuous comprehensive support for patients throughout the course of medical rehabilitation. The main organizational activity during medical rehabilitation in an outpatient setting is a comprehensive interaction of all participants in the rehabilitation process. The patient, as the central link of the rehabilitation process, must have full and reliable information about his or her state of health and understand the features of the current disease and its risks. Thus, the interaction doctor-patientrelatives, registration of organizational activities aimed at providing staff at equipment, and timely admission to an outpatient unit for rehabilitation will reduce and prevent nonmedical and indirect costs of CVA patients, enabling their return to work.

\section{REFERENCES}

1. Skvortsova VI. The medical and social significance of the problem of stroke: Quality of life. Medicine 2004; 4. 10-12.

2. Kostenko EV. A differentiated approach to the rehabilitation of patients with primary and repeated stroke. Medical alphabet. Neurology and psychiatry 2016; 22(285): 40-47.

3. Ivanova GE. Medical rehabilitation in Russia. Prospects of development. Consilium Medicum 2016; 2:1.

4. Stakhovskaya LV. Stroke. Consilium Medicum 2014; 5:1. 5. Skvortsova VI, Ivanova GE, Kispaeva TT. The delayed effect of early cognitive rehabilitation in the acute period of cerebral stroke. Clinical pharmacology and therapy 2012; 21(4):44-48.

6. Mays GP, Atherly AJ, Zaslavsky AM. The Economics of Public Health: Missing Pieces to the Puzzle of Health System Reform. Health Serv Res. 2017;52(2):2275-2284.

7. WHO. WHO recommendations on home-based records for maternal, newborn and child health. Geneva: World Health Organization; 2018.

8. Pruvo JP, Berge J, Kuchcinski G, Bretzner M, Leclerc X, Hacein-Bey L. Health Care Organization for the Management of Stroke: The French Perspective. Neuroimaging Clin N Am. 2018; 28(4):691-698.

9. Riegel B, Moser DK, Buck HG, Dickson VV, Dunbar SB, Lee CS, Lennie TA, Lindenfeld J, Mitchell JE, Treat-Jacobson DJ, Webber DE; American Heart Association Council on Cardiovascular and Stroke Nursing; Council on Peripheral Vascular Disease; and Council on Quality of Care and Outcomes Research. Self-Care for the Prevention and Management of Cardiovascular Disease and Stroke: A Scientific Statement for Healthcare Professionals From the American Heart Association. J Am Heart Assoc. 2017;6(9)

10. Duong P, Sauvé-Schenk K, Egan MY, Meyer MJ, Morrison T. Operational Definitions and Estimates of Return-toWork after Stroke: A Systematic Review and Meta-Analysis. Arch Phys Med Rehabil. 2018; S0003-9993(18)31385-6.

11. Belagaje SR. Stroke Rehabilitation. Continuum (Minneap Minn). 2017;23(1):238-253.

12. Coleman ER, Moudgal R, Lang K, Hyacinth HI, Awosika OO, Kissela BM, Feng W. Early Rehabilitation After Stroke: a Narrative Review. Curr Atheroscler Rep. 2017;19(12):59.

13. Park SW, Kim JH, Yang YJ. Mental practice for upper limb rehabilitation after stroke: a systematic review and metaanalysis. Int J Rehabil Res. 2018;41(3):197-203. 